\title{
ASSESSING THE IMPACT OF PUBLIC VENTURE CAPITAL PROGRAMMES IN THE UNITED KINGDOM: DO REGIONAL CHARACTERISTICS MATTER?
}

\author{
Federico Munari \\ Department of Management \\ Università degli Studi di Bologna \\ Via U. Terracini 28 \\ 40131 Bologna, Italy \\ Tel. $(+39)-(051)-2090208$ \\ Fax. (+39)-(051)-2090222 \\ Email: federico.munari@unibo.it \\ Laura Toschi \\ Department of Management \\ Università degli Studi di Bologna \\ Via U. Terracini 28 \\ 40131 Bologna, Italy \\ Tel. (+39)-(051)-2090214 \\ Fax. (+39)-(051)- 2090222 \\ Email: laura.toschi@unibo.it
}

\begin{abstract}
Over the last two decades, many governments around the world have implemented programmes to mobilize venture capital (VC) in support of new and innovative firms. In this paper, we analyze whether and how the impact of publicly-supported VC funds varies between high-tech and low-tech regions, when compared to private VC funds. Our analyses on a sample of 898 VC-backed companies in the United Kingdom in the period 1998-2007 show for public VC funds: (a) a greater propensity to invest in early-stage and technology-based sectors, which is especially pronounced in low-tech regions; (b) a greater propensity toward staging and a greater ability to attract partners in syndication, especially in high-tech regions; (c) lower exit rates of investee companies, in terms of IPO/acquisition, as compared to private VC funds. Overall, our findings confirm that regional characteristics do matter if we want to more rigorously assess the effectiveness of public VC programmes.
\end{abstract}

Key-words: Venture Capital, Public Policies, Regional Characteristics, United Kingdom 


\section{INTRODUCTION}

Over the last two decades, many governments and regional authorities in Europe and other countries in the world have implemented programmes to mobilize venture capital in support of newly established, innovative firms, with the objectives to remedy funding gaps in private capital markets, leverage private sector financing and fostering the creation and growth of technologybased companies. Stimulated by the implementation of such initiatives, in recent years several works in the field of entrepreneurial finance have tried to assess the effectiveness of different public policy instruments for the creation of active venture capital markets (Cumming, 2007; Cumming and MacIntosh, 2006; Lerner, 2002b). Such literature has contributed to identify successful experiences, critical aspects to design effective public venturing initiatives and potential distortions deriving from the public involvement in the $\mathrm{VC}$ market.

However, only a limited number of empirical studies have tried to take into consideration the regional dimension in the assessment of the effectiveness of public VC programmes (Lerner, 1995; Murray, 1998). The necessity to assess in more depth the influence of regional characteristics derives from the existence of "regional equity gaps", as a consequence of the uneven geographical distribution of skills, investments, innovation and entrepreneurial opportunities (Mason and Harrison, 2003; Sunley et al., 2005). The significant concentration of venture capital funds and attractive investment opportunities in certain regions, make the promotion of public venture capital funds in economically lagging regions a delicate balancing act. On the one hand, such areas have more unmet needs for VC investments, on the other hand they present higher risks that public program will fund firms with inferior business prospects. In order to address such critical issues, Gompers and Lerner (2001) suggest that public venture programs should aim at different objectives in regions and countries characterized by different stages of development of both the economic sector and the VC industry. Nevertheless, as argued by Sunley et al. (2005), “[...] at present very little is known about the character, operation and outcomes of regional venture capital policies".

Starting from such premises, this paper aims to fill this gap, by analyzing whether and how the impact of publicly-supported venturing programs varies between high-tech and low-tech regions. Following the approach of Cumming (2008), we investigate the performance of hybrid VC funds (i.e. funds backed by both private and public sector funding) as opposed to private VC funds in the different regions of the United Kingdom along three interrelated dimensions: 1) the propensity of hybrid VC funds to invest in early-stage and high-technology sectors, in order to complement investment strategies of private VC funds; 2) the capacity of public VC funds to attract qualified private VC investors in the regions, through staging and syndication investment policies; 3 ) the 
ability of public VC funds to invest in and promote successful companies, by analyzing their exit rates (in terms of IPO, mergers or acquisitions, write-offs). In all the cases, we try to assess whether such differences are more or less pronounced in low-tech regions as opposed to high-tech regions. We provide empirical evidence from a sample of 898 companies backed by hybrid and private VCfunds in the United Kingdom over the period 1998-2007. We decided to focus on the experience of the United Kingdom since its VC industry is relatively more developed than in other European countries and it has implemented several important direct policy measures to support VC investments over the last decade, starting from the "Competitiveness White Paper" published in 1998 (Nightingale et al. 2009). Our univariate and regression analyses confirm that regional characteristics do matter if we want to more rigorously assess the effectiveness of public VC programmes, given that important differences emerge between high-tech and low-tech regions.

Our results show that hybrid VC funds have: (a) a greater propensity to invest in early-stage and technology-based sectors, which is especially pronounced in low-tech regions; (b) a greater propensity toward staging and a greater ability to attract partners in syndication, especially in hightech regions; c) lower exit rates of investee companies in terms of IPO/acquisition as compared to private VC funds, and significantly lower write-off rates in low-tech regions.

Overall, our findings provide a mixed picture as to the contribution of hybrid VC funds in closing the regional equity gaps. On the one hand, they highlight a positive orientation towards investing in types of companies and sectors that tend to be neglected by private VC funds, an effort which is particularly evident in low-tech regions. On the other hand, they show that profound differences remain between hybrid and private VC funds, along several performance measures, and that the gap is often more pronounced in low-tech regions.

The rest of the paper is structured as follows. In section 2, we present the theoretical background related to government interventions in support of VC investments by highlighting and discussing the presence of regional equity gaps. In section 3, we present a brief overview of the governmentsupported VC funds in the United Kingdom, we describe the sample and data sources and we define our variables. In section 4, we show the results from the univariate statistics and logit and Poisson regressions. The last section discusses the main findings and policy implications.

\section{BACKGROUND}

In this section, we first briefly provide a rationale for the government intervention in support of VC investments and discuss then the importance of considering in more depth the existence of regional 
disparities in the supply/demand of risk capital to new technology based firms. We then illustrate how the regional dimension can be incorporated in the assessment of the different policy initiatives.

\subsection{Government policies for VC investments and regional equity gaps}

The rationale for the government intervention to improve the access of small firms to equity financing is usually rooted in the financing gap argument, that is the limited availability of private venture capital investments in high-tech, early stage companies (Lerner, 2002b; Lockett et al., 2002; Wright and Robbie, 1998). The economic literature suggests that the motives for public intervention in favoring SMEs' ability to encounter barriers to access to private financing means are twofold (Lerner, 1999): 1) the spillover hypothesis, suggesting that SMEs are able to generate positive externalities, by creating new jobs, new ideas, and new abilities that other industries and the economy as a whole may enjoy (Cressy and Olofsson, 1997, Lerner, 1999, Cressy, 2002, OECD, 2004, European Commission, 2005); 2) the existence of market failures, such as the presence of asymmetric information in terms of adverse selection and moral hazard (Hyytinen and Väänänen, 2006). Thus, the availability of risk capital for small and highly innovative companies, newlyestablished enterprises, and firms located in depressed areas has been a key policy issue for governments in different countries of the world in order to promote not only the growth of these companies, but also of the whole economic development.

Governmental bodies around the world are paying increasing attention to the finance of such innovative firms through different types of indirect and direct measures (Poterba, 1989, Lerner, 1999, Gompers and Lerner, 2001, Gilson, 2002). Indirect measures aim at creating proper economic, institutional and regulatory frameworks within which markets can effectively channel resources to new and innovative enterprises (OECD, 1997). For instance, governments can facilitate the development of stock markets, determine a favorable fiscal treatment for equity investments, support entrepreneurship, favor networking among entrepreneurs and investors. In this paper we explicitly focus on a second set of direct measures, related to publicly-funded schemes which aim to increase the supply of venture capital financing. Such schemes can be either directed to small and medium enterprise, as in the cases of public funds directly invested in individual portfolios of SMEs, or indirectly channeled to venture capital firms. In this latter case, indirect support occurs since the government (or other regional or local public authorities) invests as a limited partner in one or more professional venture capital funds (Poterba, 1989, Gilson, 2002, Kanniainen and Keuschnigg, 2004, Avnimelech and Teubal, 2006, Cumming, 2007). The involvement of commercially motivated, private sector investors acting as 'agents' on behalf of government 
'principals' in managing so-called "hybrid funds" has now become the predominant modus operandi in several countries of the world (Jaaskelainen et al., 2007).

It is noteworthy that several public venture programmes established over the last decade in a wide variety of countries - including Belgium, Canada, France, Germany, Italy, Spain, and the United Kingdom - have had an important regional dimension, either because they were promoted and/or managed by regional authorities, or because they operated on a regional basis ${ }^{1}$. According to Sunley et al. (2005) there are three main motivations in support of regionally-oriented venture capital programmes. The first one states that they can better respond to specific regional conditions and problems, thanks to the establishment of closer relations and direct interactions between investors, entrepreneurs and supporting institutions. Indeed, there is ample evidence in the literature that local proximity between the venture capital firms and the investee companies is an important condition for the success of early-stage investments (Cumming and Dai, 2009). Second, regional venture capital programmes could be better coordinated with other locally-oriented innovation policies aimed at fostering the creation and development of high quality, high potential firms worthy of investment. Third, venture capital programs with a regional dimension might better address regional equity gaps and market failures, origintating in specific regions. Indeed, previous research has emphasized that there are significant differences in $R \& D$ and innovation intensity across regions, that are associated with differences in innovation performance and economic growth (Mason and Harrison, 2003). In a similar vein, private venture capital investments tend to be strongly concentrated in a limited number of economically advanced regions, characterized by the presence of promising entrepreneurial opportunities (Cumming and Dai, 2009; Powell et al., 2001; Sorenson and Stuart, 2001). At the same time, previous studies have emphasized the distortions and problems which can derive by an excessive regionalization of public venture capital programs such as (a) the lack of valuable entrepreneurial opportunities with high growth potential, (b) the propensity to support politically connected firms with few growth prospects and (c) the lack of experience and skills of local VC investors (Lerner, 1999; Mason and Harrison, 2003).

Overall, empirical evidence on the effectiveness of publicly-supported VC programs, which takes into account regional characteristics, is largely missing. A notable exception is represented by the study of Lerner (1999) on the long-run impact of the Small Business Innovation Research Program

\footnotetext{
${ }^{1}$ For instance, nine Regional Venture Capital Funds (RVCFs) were launched starting from 2002 in the United Kingdom, representing a $£ 250$ million investment programme supported by the private sector along with $£ 74$ million of Government investment. In Germany, most states have established in the 1990s new venture capital firms with a public majority share (in most cases held by the relevant Landesbank and/or regional development agencies) (Sunley et al., 2005). In different regions of Italy, such as Toscana, Lombardia, Piemonte and Emilia-Romagna, several hybrid funds have been established over the last decade, pooling financial resources from the regional authorities and from private investors.
} 
in the United States, showing that the superior performance of SBIR awardees (in terms of employment and growth rates) as compared to matched companies was confined to firms in regions with substantial venture capital activity. However, systematic evidence from other countries and other types of public programmes is largely missing. Moreover, in order to fully capture differences across regions in the effectiveness of public venture programs, it is necessary to take into consideration a wide set of performance dimensions, as we will discuss in the next section.

\subsection{How to assess the impact of public venture capital programmes at the regional level?}

Different approaches have been used in the economic and finance literature in order to assess the impact of government support to venture capital. A first approach adopts a macro-level of analysis, focusing on the relationship between public and private sources of venture capital at the regional or country level, in order to assess the existence of complementarity vs. substitution between the two forms. At the region level, for instance, the study by Cumming and Macintosh (2006) analyzes the effects of a Canadian tax-driven venture capital vehicle (LSVCC) on the supply of private venture capital funds in different Candian geographic regions. At the country level, the work of Leleux and Surlemont (2003) investigates the effects of publicly sponsored or managed venture capital funds in the development of national venture capital markets in 15 European countries.

A second approach focuses on the level of the VC fund, trying to assess the financial performance of publicly supported VC funds relative to private VC funds (Cumming and Macintosh, 2003; Brander et al., 2002). For instance, the study of Murray (1998) on the European Seed Capital Fund Scheme highlights that the target Internal Rate of Return (IRR) for the managers of the publiclysupported VC funds were significantly lower than the target IRR for commercial VC funds' managers.

A third approach looks at the characteristics and economic performance of the companies funded by publicly-supported VC funds vis a vis a comparable sample of other companies, as in the paper of Lerner (1999) previously mentioned. In a recent report on venture-capital schemes backed by both private and public sector (so-called hybrid VC funds) in the United Kingdom, Nightinghale et al. (2009) compare the performance of 782 companies funded by hybrid VC funds against similarly matched companies, in terms of general capacity building, profitability and labour productivity. Their econometric analyses show that such schemes have had a positive effect on firm performance, encouraging the involvement in growth-oriented investment behavior. Cumming (2007) studies the performance of companies funded under the Innovation Investment Fund (IIF) governamental program in Australia relative to those backed by other types of private equity and venture capital 
funds, presenting positive evidence on the fact that the IIF has fostered the development of the VC industry in Australia.

We decided to adopt this latter approach in our regional-level analysis of the impact of government supported VC funds. More precisely, we focus on the characteristics and performance of companies backed by publicly supported VC funds (so-called hybrid VC funds) as compared to private VC funds, trying to assess whether differences emerge between high-tech and low-tech regions. As in the study of Cumming (2007), we perform the comparison along three different dimensions that are particularly coherent with the objectives of public venture programmes: a) the propensity to invest in early-stage, high-tech ventures, in order to fill the equity gap; b) the ability to attract additional venture capital in the region, through staging and syndication policy; c) the exit outcome for portfolio companies.

Concerning the first dimension, there is wide evidence that private venture capitalists tend to have a bias against investing in very early stage companies, due to the high levels of risks and the presence of significant information asymmetries (Murray and Lott, 1995; Lockett et al., 2002). Moreover, they tend to concentrate on a few industries (typically ICT and healthcare), which present the highest growth potential, and tend to neglect opportunities in other areas. Therefore, a first critical objective for public VC programs should be that to promote investments in stages and technologies which are not popular among private venture investors. As to this point, Gompers and Lerner (2001) argue that the focus of public intervention should differ between more developed countries or regions and less developed ones. In the former case, in regions where an active venture capital sector is already present, the main focus of public venture programs should be that to complement the private sector. This means that we should observe hybrid funds strongly concentrated in seed/start-up companies (with the private sector typically concentrated in early-stage/expansion phases) and more diversified in terms of industry (with the private sector typically concentrated in sectors with high growth potential, such as healthcare and ICT). On the other hand, in economically lagging regions, a primary objective of government intervention should be that of creating a venture-investing infrastructure, supporting start-ups in novel and more technologically-advanced sectors. Our empirical analyses will therefore first compare the propensity of publicly supported VC funds to invest in seed/start-up firms and in high-technology sectors relative to their private counterparts, in order to assess differences between high-technology and low-technology regions.

As concerns the second dimension of interest - the ability to attract private venture capital in the regions - a major objective of public venture schemes should be that to act as a catalyst in order to encourage the involvement of major VC funds in the region. Such priority is particularly relevant for less developed regions, given that the localization of venture capital firms tends to be spatially 
concentrated in high-tech and financial hotspots, such as the Silicon Valley or the Boston Area in the United States, or London and the South East in the United Kingdom². Moreover, an effective government program should aim not only to attract private venture capitalists' financial resources in the region, but also qualified investment expertise and extensive contact networks. A very successful government effort to this purpose is represented by the Yozma Venture Capital Fund established by the Israeli government in 1992, with the goals to encourage the involvement of major international corporations in the Israeli technology sector and to stimulate the development of a professionally managed, private VC industry in the country, by bringing in foreign venture capitalists' investment expertise (Avnimelech and Teubal, 2006).

We will therefore compare the staging frequency and the propensity to syndicate of publicly supported VC funds relative to their private counterparts in both high-tech and low-tech regions. As an additional contribution to previous literature, we will not just focus on the number of different funds involved in syndication networks, but also on their relative quality and ability to provide a significant contribution for the local economic and innovative growth. To this end, we will consider also the propensity to syndicate with foreign (i.e. non-UK based) VC firms and with corporate venture capital firms.

Finally, the third dimension of impact that we consider focuses on exit performance as an objective way to assess the entrepreneurial company performance and the success of its venture capital investors. Previous literature has widely referred to the achievement of a positive exit for the investee company through IPO or trade sale, both at the fund level (i.e. Hochberg et al., 2005) and at the company level (i.e., Cumming, 2007; Gompers et al., 2005). The rationale refers to the fact that VC firms are able to earn a capital gain from their investments only in the case of an exit through IPO or a sale to another company. We could expect to observe significant differences in the exit rates of companies backed by public VC funds between high-tech and low-tech regions, for at least three different reasons. First, managers of public VC funds in less economically developed regions might subordinate the achievement of relevant financial objectives to wider developmental goals (Murray, 1998) ${ }^{3}$. Second, they might be unable to find sufficient investment opportunities, in terms of number of firms with high enough potential growth rates. This could results in distortions such as investments in underachieving companies or in more politically-connected ones (Lerner,

\footnotetext{
${ }^{2}$ For instance, Powell et al (2002) found a strong pattern of spatial concentration of new enterprises and venture capital firms in the biotech sector in the United States, with considerable number of both to be found in in the Bay Area and in Boston. Mason and Harrison (2003) highlight the uneven distribution of VC investment activity in UK regions, with London and the South East having around 40\% of all VC investments in the period 1997-2001.

${ }^{3}$ In an assessment of the European Seed Capital Fund Scheme, Murray (1998) found that the opinions of managers of publicly-supported, regional VC funds diverged significantly from those of commercial VC funds in terms of minimum level of financial attractiveness of a business opportunity, as measured by the target Internal Rate of Return (IRR).
} 
1999) ${ }^{4}$. Third, experienced venture capitalists with sophisticated investing skills and wide relational networks are more likely to be located in economically advanced regions, due to the spatial concentration of VC activity (Mason and Harrison, 2003). Following such arguments, in our empirical analyses we will try to determine the existence of differences of exit performance (both in terms of likelihood to reach an IPO/acquisition or, on the contrary, a write-off) between high-tech and low-tech regions, for what concerns publicly-supported $\mathrm{VC}$ funds vis a vis private ones.

\section{DATA AND METHODS}

\subsection{The empirical setting: government-supported VC funds in the United Kingdom}

We chose as empirical setting for our analyses the VC industry in the United Kingdom, since it is the largest and most developed in Europe and it is second to the USA in world importance. In addition to that, in the UK there is a long tradition and experience with government interventions in favour of equity investments in start-up companies (Nightingale et al., 2009), starting from the late 1945 with the formation of the Industrial and Commercial Finance Corporation (ICFC). However, the biggest changes started after the 1979 election, with an increased emphasis on small firms as sources of job creation and economic growth to be further exploited and the subsequent introduction of the Small Firm Loan Guarantee Scheme (SFLGS) in 1980 and the Business Start up Scheme in 1981 (then substituted by the Business Expansion Scheme in 1983) to address market failures.

In the nineties, the Enterprise Investment Scheme (EIS) and the Venture Capital Trusts (VCTs) introduced tax incentives to encourage informal and private (i.e. non-institutional) investors to provide greater sums of seed, start up and early growth risk capital finance (Cowling et al., 2008). VCTs attracted mainly retail investors seeking exposure to a diverse portfolio of venture investments, while EIS appealed principally to informal investors (Boyns et al., 2003). A new and sizeable wave of public support occurred after the introduction of the Competitiveness White Paper in 1998, to support knowledge-based firms with high levels of intangible assets that had less collateral to achieve loans and, thus, were particularly suitable for equity financing. With this document, the UK government announced and later developed a broad range of hybrid VC funds designed to support small, innovative and growth-oriented companies. A $£ 270$ million Enterprise Fund and an Early Growth Fund were introduced to address market weaknesses and to favour

\footnotetext{
${ }^{4}$ The study of Lerner (1999) on the effects of the SBIR program in the US shows that the significantly superior growth of SBIR awardees with respect to matched companies was confined to awardees located in high-tech regions. It also highlights the ability of particular companies (so-called "SBIR mills") to capture a disproportionate number of awards, thanks to their behavior as active lobbysts.
} 
investments in start-up and early-stage businesses respectively. The creation of the UK High Tech Fund of Funds had the aim to support existing technology-based VC funds by gathering over $£ 100$ million from new institutional investors and modify the wrong perception that investments in technology produce lower commercial returns. This intervention was complemented by the creation of University Challenge Funds (UCF), introduced to provide technological and commercial support to academic spin-offs, a particular group of small and innovative companies deriving from universities. In addition to that, nine Regional Venture Capital Funds (RVCFs) and other specialist VC funds were created to provide support for smaller-scale (below $£ 500,000$ ) equity investments in young, risky and high potential companies across England. Lastly, the Early Growth Funds (EGF) were based on the collaboration with the angel community to ensure that every UK region had access to early growth funding of up to $£ 100,000$ per recipient firm (Nightingale et al., 2009).

In addition to such direct measures, other interventions were introduced to increase the quality of companies seeking equity financing. Some examples of these interventions were the six investment readiness demonstration projects launched in 2002 with the logic to work in coordination with Regional Development Agencies and create suitable programmes at a local level to increase the flow of valuable investment opportunities and launch, in a second stage, a national investment ready programme following the evaluation of the preliminary pilot projects.

The effects of some of these government interventions in the market for equity have been econometrically evaluated in a recent report for the British Venture Capital Association and the National Endowment for Science, Technology and the Arts by Nightingale and colleagues (2009). The results suggest a positive impact on firm performance, when compared to a matched control sample. However, in terms of magnitude, the size of their impact is quite small.

At the light of this broad pool of public interventions, the United Kingdom represents a suitable context to increase our understanding of this type of financing by focusing on their investments decisions and outcomes in the different regions. Furthermore, the skewed distribution of UK small and innovative companies among the UK regions allows us to assess if the impact of these publiclysupported venturing programs varies between high-tech and low-tech regions.

\subsection{Sample and data sources}

In order to construct our sample we first identified all the companies funded by VC funds in the United Kingdom over the period 1998-2007 according to Venture Economics ${ }^{5}$. We decided to start

\footnotetext{
${ }^{5}$ Coherently with the definition of venture capital adopted in this paper, we referred only to investments made in new or young companies, extracting data from Venture Economics related only to seed/start-up/early-stage rounds.
} 
our data collection from 1998 since in that year the UK government published the Competitiveness White Paper establishing an ambitious program to support venture capital provision throughout the UK, that was implemented through the formation of several hybrid funds in partnership with the private sector, as described in the previous section.

Following such criteria, we found 932 companies in Venture Economics. However, it was not possible to assign 34 of them to their respective regions, since information on company address was missing or incomplete. Therefore, our finale sample includes 898 companies backed by hybrid VC funds (243 companies) and private VC funds (655 companies) over the period 1998-2007 in the United Kingdom. However, since information on company age is restricted to 653 companies, our regression analyses are performed on this smaller sample.

For each investee company, we collected the following information through Venture Economics: name, founding year, stage of development, location, country, main industry (according to the Venture Expert Industry Classification), number and date of all funding rounds, amount received in each investment round, VC funds involved in each investment round, status (active investment, IPO, merger or acquisition, write-off) as of end of December 2007.

For each VC-fund identified in the previous step, we collected the following information: VC fund name, vintage year, managing $\mathrm{VC}$ firm, total amount raised, country of origin, investment stage focus, number of portfolio companies, type. We complemented information taken from Venture Expert on VC funds and portfolio companies by using other data sources, as described in more depth in the following section.

Data on R\&D and innovation intensity and outcomes for the different regions of the United Kingdom were obtained by the Regio database of Eurostat.

\subsection{Variables}

A listing of the variables used in the empirical analysis along with their definitions is provided in Table 1 below. It first specifies our dependent variables, divided into three major groups coherently with the approach of Cumming (2007), as described in Section 2.3: a) variables capturing the propensity to address the equity gap, by investing in early stage and high-tech companies; b) variables capturing the ability to attract additional venture capital, through staging and syndication; c) variables capturing the exit success of investee companies. Table 1 then presents the explanatory and control variables adopted in the analyses. A more detailed explanation for the choice and construction of the two explanatory variables now follows. 
Insert Table 1 about here

Identifying hybrid funds: in order to fully capture the influence of publicly-supported VC funds in the various regions, it was necessary to identify the companies financed by at least one hybrid fund (that is, a fund backed by both private and public sector funding). To this purpose, we initially resorted on the classification provided by Venture Economics, which identifies different categories of VC firms: Private Equity, Pension Funds, Financial Institutions, Corporations, Foundations and Endowments, Corporate, Venture Program, Service Providers, Individuals, and Other. The category "Venture Program" was of particular interest for our purposes, since it includes the following subcategories related to different forms of public sponsorship for VC investments: Government affiliated program; University affiliated program; Business Development Fund; Incubators; Other Government programs. However, it was necessary to complete and extend this initial sample in order to have a more precise picture of companies backed by hybrid funds ${ }^{6}$. To do that, we tried to identify the names of all the hybrid VC funds activated in the UK over the period 1998-2007, by using the following data sources: the website of the UK Department for Trade and Industry; the OECD report on venture capital policy in the UK (OECD, 2003); the report of Nightingale et al. (2009) on hybrid funds in the UK; the articles by Mason and Harrison (2003) and Sunley et al. (2005) on government VC policies in the United Kingdom. We then identified all the investee companies related to those funds for which information was available in Venture Economics ${ }^{7}$.

We finally created a dummy variable Hybrid VC fund equal to 1 for all the companies backed by at least one hybrid VC fund, and 0 in all other cases (corresponding to companies exclusively backed by private VC funds).

Assigning investee companies to high-tech and low-tech regions: In order to identify the regional distribution of venture capital activity, we assigned investee companies to the different regions of the United Kingdom, using the NUTS (Nomenclature of Territorial Units for Statistics) system of Eurostat $^{8}$. We related the location of each company (as reported in terms of mailing address and zip

\footnotetext{
${ }^{6}$ A major problem with the classification provided by Venture Economics stems from the fact that, in most of the cases, hybrid funds established in the UK are run by private VC general partnerships. Venture Economics tends often to classify such funds under the label "Private Equity" (and not "Venture Program"), even tough an important share of the money committed to the Fund comes from public sources.

${ }^{7}$ We therefore identified all the companies included in the Venture Economics database (as of December 2007) backed by funds established with the 1998 Competitiveness White Paper: Enterprise Capital Funds, Early Growth Funds, Regional Venture Capital Funds, Community Development Funds. In addition to that, we covered other significant national or regional level initiatives (i.e. NESTA, Scottish Enterprise Funds, Welsh Hybrid Equity Funds, Invest Northern Ireland) and funds investing in socially benefiting sector thanks to public support (i.e. Low Carbon Seed Fund, Global Rights Funds).

${ }^{8}$ The NUTS system is a geographic code standard for referencing the administrative divisions of countries of the European Union for statistical purposes. It encompasses three different levels (NUTS-1; NUTS-2; NUTS-3) and a
} 
codes in Venture Economics) to UK regions identified at the NUTS-2 level. In order to separate high-technology regions from low-technology regions, we then collected information at the regional level from the Regio database of Eurostat on the following key variables of economic and technological development: GDP/capita; number of patent filings per million head; share of employment in high and medium high-tech manufacturing sectors. We used this latter category as a proxy of the degree of innovation intensity of the region. Indeed, the Eurostat regional yearbook (Edition 2009) classifies the different regions of Europe (at the NUTS-2 level) into 4 different classes: percentage of total employment in high and medium high-tech manufacturing sectors less than $5 \%$; between $5 \%$ and $10 \%$; between $10 \%$ and $15 \%$; more than $15 \%$. We therefore used the value of $10 \%$ as a cut-off point to separate high-tech regions (share of total employment more than $10 \%$ in high and medium high-tech manufacturing) from low-tech regions (share of total employment less than $10 \%$ in high and medium high-tech manufacturing). We than created a dummy variable High-tech Region taking the value 1 for companies located in the former group of regions, and 0 for those located in the latter. Table A1, in the appendix, reports a list of the 36 different regions in the UK, with the corresponding value of the dummy variable High-tech region.

\section{ANALYSES AND RESULTS}

\subsection{Graphical presentation of the data}

A time series of all investments (in terms of number of investee companies) in the UK from 1998 to 2007 is provided in Figure 1. As shown by the graph, the UK venture capital industry shares the wave-trend characterizing also other VC markets, like the US (Lerner, 2002a, 2002b), Canada (Cumming and MacIntosh, 2006), Europe (Armour and Cumming, 2006) and Australia (Cumming, 2007). In all these cases, and in particular for the UK, VC investments showed a drastic increase in the years 1999 and 2000 leading up the beginning of the end of the bubble in April 2000.

Insert Figure 1 about here

Figures 2 and 3 presents the detail of $\mathrm{VC}$ investments in terms of type of fund and region respectively. It is evident the increasing importance of the public intervention, through the introduction of public funds, starting from the early 2000s (Figure 2) and the strong concentration 
of equity investments in regions with high technological intensity (Figure 3). Interestingly, major differences in the numbers of companies backed by hybrid VC funds or private ones, or in the numbers of companies funded in high-tech or low-tech regions, seem to be concentrated in the years of the Internet Bubble, whereas they tend to shrink in the following years. This first evidence confirms that public programmes played an important role in supporting equity investments in newly established, high-tech companies, once the period of irrational exuberance related to the Internet bubble had expired.

Insert Figure 2 and 3 about here

\subsection{Descriptive and univariate statistics}

Table 2 summarizes the data from our sample of VC-backed companies that we use in our subsequent analyses. 27\% of our companies are financed by hybrid funds, whereas $73 \%$ of them belong to regions with a share of employment in high-tech sectors greater than $10 \%$. About $42 \%$ are companies in the seed/start-up phase. In terms of industry, 57\% belong to high-tech sector (and more precisely, $20 \%$ from the biotech/medical/health sectors and $37 \%$ from ICT). On average, the companies included in our sample received 1.5 financing rounds by 1.85 different VC firms involved in syndicated partnerships. On average, 0.56 (around one third) of syndicated partners are investors located outside the UK, and only 0.122 are corporate investors. The average age of VC funds, which can be considered a proxy of the investors' experience, is 9 years. Only $16 \%$ of our sample companies received an IPO or have been acquired by other firms at the end of 2007, whereas less than $7 \%$ of them were defunct or filed for bankruptcy. The mean age of the company at date of the initial VC investment is around 7 years and the average duration of the VC involvement per company is 5 years at the end of 2007.

Insert Table 2 about here

A correlation matrix for the variables across the 898 investee companies is provided in Table 3 . The statistics provide insights for possible problems of collinearity among the variables for different investee companies which is useful for correctly designing the econometric models used in the next section. Table 3 suggests that multi-collinearity problems among variables do not exist. 
Insert Table 3 about here

Table 4 provides univariate comparison tests for companies backed by hybrid versus private VC funds for the full sample (panel A) and for the split samples, by distinguishing between high-tech and low-tech regions (panel B and C). These tests, by examining differences in proportion and means for each of the dependent variables used in our model, indicate the trends in the data and provide preliminary insight into the degree to which the data support differences between hybrid and private funds by taking into account also regional differences.

Insert Table 4 about here

Our univariate comparison tests in Table 4 - Panel A indicate the following results:

1. Hybrid funds are more likely to finance companies in the seed/start-up phase than private investors, and these differences are significant at the $1 \%$ level of significance.

2. Hybrid funds are more likely to finance companies operating in high-tech sectors than private investors, and these differences are significant at the $1 \%$ level of significance.

3. There are not significant differences between hybrid and private funds in their staging strategies.

4. Hybrid funds tend to syndicate more than private investors, and these differences are significant at the $1 \%$ level of significance.

5. Hybrid funds are slightly less able to attract foreign investors than private funds (this difference is significant at the $10 \%$ level of significance), but are more able to attract corporate investors (this difference is significant at the $1 \%$ level of significance).

6. Hybrid funds have a lower performance in terms of number of companies undergoing an IPO or an acquisition exit than private investors, and these differences are significant at the $1 \%$ level of significance.

7. Finally, there are not statistically significant differences in terms of failure rates between hybrid and private funds.

Our additional comparison tests introducing the distinction between high-tech and low-tech regions are shown in Table 4 - Panel B and indicate the following evidence:

1. Hybrid funds are more likely to finance seed stage companies than private investors, both in high-tech and low-tech regions with a slight difference in terms of significance (5\% level for high-tech regions and $1 \%$ level for low-tech regions). The percentage of investments 
made by hybrid funds in the seed/startup phase is significantly larger in low-tech regions (62\%) as compared to high-tech regions (49\%), suggesting a stronger risk-propensity in the former context.

2. Hybrid funds are more likely to finance companies operating in technology-based sectors than private investors both in high-tech and low-tech regions, but the difference in the two contexts is impressive both in terms of shares (respectively 62\% vs. 79\%) and statistical significance (5\% level for high-tech regions and $1 \%$ level for low-tech regions). This suggests a strong orientation towards supporting the development of new technological capabilities and companies in low-tech regions.

3. There are not statistically significant differences between hybrid and private funds in their staging strategies in both high-tech and low-tech regions, although the former present on average a higher number of financing rounds in the case of hybrid funds than the latter (respectively 1.59 vs. 1.40).

4. Hybrid funds tend to syndicate with more partners than private investors only in high-tech regions, and this difference is significant at the $1 \%$ level of significance. This evidence signals a more limited ability of hybrid funds in low-tech regions to attract private VC firms in their investment choices.

5. Hybrid funds seem to be less able than private VC funds to involve in syndicated deals foreign VC firms, in both high-tech and low-tech regions. However, in low-tech regions the percentage of foreign VC firms collaborating with hybrid funds reaches the lowest value (0.33). This suggests that the relational capabilities and attraction power of publiclysponsored VC funds in less developed areas represent a major challenge.

6. Hybrid funds have a lower performance in terms of number of companies undergoing an IPO or an acquisition offer than private investors in both high-tech and low-tech regions, but this difference is more evident in high-tech regions (1\% versus $10 \%$ level of significance for high-tech and low-tech regions respectively). Once again, the percentage of successful exits reaches the lowest value for hybrid funds in low-tech regions (7.7\%), although it is not so different from their counterparts in high-tech regions $(8.4 \%)$.

7. Finally, there are not statistically significant differences in terms of failure rates between hybrid and private funds in both high-tech and low-tech regions. It is interesting to notice, however, that the percentage of write-offs for hybrid funds in low-tech regions is lower $(5 \%)$ than in the case of private funds $(10 \%)$, and it is also slightly lower than the values observed in high-tech regions for both hybrid and private VC funds (around 6\%). In the light 
of previous evidence, we can interpret such results as a signal of the higher propensity of hybrid VC funds in low-tech regions to maintain active investments.

\subsection{Regression analyses}

We analyze the different investment strategies and performance between hybrid and private funds under different regional environments in a regression framework, in order to control for the potential influence of other factors. For all the specifications of our model, we control for three different types of variables: (a) market conditions through the Morgan Stanley Capital International (MSCI) index in the year of investment and a dummy variable equal to one for the bubble years of 1999 and 2000, (b) characteristics of the investee companies in terms of age and first VC investment year (as measured by investment duration at December 2007) and (c) fund characteristics in terms of average age of all the funds involved in syndication, to take into account the experience of the investors engaged in the financing process.

In line with Cumming (2007) we define the following econometric models. For the regressions adopting Seed, High-tech Industry, IPO/Acquisition and Failure as dependent variables, we used a logit specification due to the binary nature of our variables. This model allows to assess the probability of the different types of fund to invest in seed companies, technology-based industries, obtain a positive exit (IPO or acquisition) and fail respectively. In the models related to staging, syndication, ability to attract foreign investors and corporate investors, instead, we used Poisson regressions. This model, indeed, is useful to deal with skewed distributed dependent count variables (Table 2, for instance, shows that the mean value of the variable staging is 1.5 so that the many investees have only one or two staged financing rounds, and a maximum value of 11 rounds suggesting that fewer investees are staged more frequently).

We proceed into two steps. First, we perform our analyses on the full sample including all 650 investee companies (due to missing value in the variable Company Age). Then, we analyze whether and how differences between hybrid and private funds change when we introduce the regional dimension. In order to do that, we split our observations into two sub-samples depending on the percentage of employment in high-tech sectors. Thus, we distinguish between a sample of 489 observations for high-tech regions (High-tech Region =1) and a sample of 161 observations for lowtech regions (High-tech Region $=0$ ). 
We first start discussing differences in the investment strategies of the funds, in terms of stage of development and industrial focus. Table 5 - Panel A presents the results for the Seed variable. Model 1 (which refers to the full sample) indicates that hybrid funds are $21.1 \%$ more likely to finance seed stage companies than private funds. When we split the sample between high-tech and low-tech regions (to assess the combined effect of the type of fund and regional characteristics) we find a significant difference in the investment decisions between hybrid and private funds especially in low-tech regions (marginal effects for the variable Hybrid VC Fund is 0.308 for low-tech regions and 0.184 for high-tech regions both at the $1 \%$ level of significance).

Table 5 - Panel B shows the results for the industry focus. By distinguishing between technologybased and non technology-based sectors ${ }^{9}$, we find that hybrid funds tend to invest more in high-tech sectors when compared to private funds ( 0.111 at the $5 \%$ level of significance). Interestingly, in the split sample analyses, this difference is confirmed only in low-tech regions. This confirms previous evidence from univariate analyses, highlighting a strong orientation of hybrid funds towards the renewal of the business environment in regions with apparently less opportunities of growth.

Insert Table 5 about here

\section{Staging and syndication}

As far as the ability of different types of funds to attract additional VC investments through a greater number of financing rounds or syndicated investors is concerned, the analyses on the full sample show the following evidence. There seems not to be any difference in terms of number of staging in the full sample, but the ability to involve other investors in syndication is greater for companies backed by hybrid VC funds than those backed by private VC funds. However, when we split the sample according to regional characteristics, we find that hybrid VC funds tend to have a greater performance in terms of staging when they operate in high-tech regions, but not when they operate in low-tech regions. Finally, when we analyze the type of investor in syndication, we find that hybrid and private $\mathrm{VC}$ funds do not present significant differences in their ability to attract investors that reside outside the UK (even if regional characteristics have an effect in favor of hightech regions). On the contrary, hybrid VC funds seem to be more able in attract corporations only when they operate in high-tech regions.

\footnotetext{
${ }^{9}$ As robustness check, we also analyzed differences in terms of industry at a more detailed level by distinguishing between health, ICT and non-technology industries. Our results confirm a greater propensity of public VC funds to invest in pharma and biotech industries, followed by ICT. Only a small proportion of public funds invest in nontechnology sectors.
} 
Insert Table 6 about here

\section{Exit success of investee companies}

The last group of dependent variables intends to assess differences in the exit rate (in terms of IPO/acquisition or write-offs) between companies financed by hybrid versus private funds. Our results, shown in Table 7, suggest the absence of significant differences between the two types of funds both in the full and the split sample, once we control for company-, fund-, environmentalcharacteristics. However, the analyses of failure rates of the investee companies show different results. In the full sample, again, hybrid and private funds present similar trends, but differences at the regional level matters with a greater probability to fail in low-tech regions (the marginal effect of the variable High-tech Region is equal to -0.0429 and significant at the 5\% level). However, the split sample shows that the probability of failure is higher when the investee company belongs not only to a low-tech region but it is also financed by a private fund. When coupled with previous findings, which do not show a superior positive performance of companies backed by hybrid funds in low-tech regions (if not an inferior one), this evidence suggests a greater propensity of hybrid funds in less developed regions to maintain active their investments.

Insert Table 7 about here

As far as our control variables, under "good" market conditions (according with the MSCI index), the frequencies of stages and syndication decrease both in the full sample and in the split sample referred to high-tech regions, but this is not a significant factor in low-tech regions. Finally, as expected, it is negatively related to the frequency of failure of the investee companies (MSCI equal to -0.264 in low-tech regions at the $10 \%$ level of significance). Surprisingly, the environment conditions do not impact significantly on the successful exits (IPO plus acquisition) in all the models. The coefficient and significance level of the Bubble variable show that the propensity to invest in high-tech sectors, the number of financing rounds and the frequency of syndication decreased around the period 1999-2000 of the Internet bubble. The Company Age variable shows that younger firms tend to receive a greater number of financing rounds due to the higher levels of uncertainty in their business model and make the possibility of syndication more difficult. Accordingly, the Investment Duration variable increases for investments in seed companies and it has, as expected, a positive and statistically significant impact on the exit outcomes (the older the date of the first investment round by a VC, the more likely the possibility to reach an 
IPO/acquisition or, on the contrary, a write-off). Finally, the average age of the funds investing in our sample companies is greater in seed investments in low-tech regions, decreases when the number of round increases and increases for higher frequencies of syndication and when the number of foreign funds in syndication is higher. These results suggest that the age of funds, as proxy for the experience of investors in equity financing, is an important explanatory factor.

\section{CONCLUSIONS}

The aim of this paper has been to assess the effectiveness of hybrid VC funds for the creation of active venture capital markets by taking into consideration also regional characteristics, as a consequence of the existence of significant "regional equity gaps" (Mason and Harrison, 2003). In particular, we were interested in investigating whether and how the impact of publicly-supported programs varies between high-tech and low-tech regions in the UK along three interrelated dimensions: the propensity to invest in early-stage and high-technology sectors, the capacity to attract qualified private VC investors and the ability to invest in and promote successful companies. Our results confirm that regional characteristics do matter if we want to more rigorously assess the effectiveness of public VC programmes, given that important differences emerge between high-tech and low-tech regions in the above mentioned dimensions.

They also draw a mixed scenario as to the contribution of hybrid fund in closing the regional equity gaps. On the one hand, we highlighted a number of encouraging findings suggesting that the role of government in addressing the equity gap is critical and effective. Hybrid funds tend to finance more than private $\mathrm{VC}$ funds seed/start-up companies operating in technology-based sectors such as the ICT or the pharmaceutical industries. This attempt is particularly pronounced in low-tech regions, whereas it is weaker in more high-tech regions, consistently with the aim of complementing private VC funds in that areas, that tend to be more concentrated in such sectors. This finding is in line with the explicit objective formulated by public programmes to support the creation and growth of new and high potential firms for fostering innovation, research and development, entrepreneurship, economic growth and job creation. It should be stressed, however, that the strong orientation of hybrid VC funds towards high-tech sectors in economically lagging region (particularly pronounced in the case of biotech/medical/health investments, according to our data) might involve significant risks of backing underachieving companies. Finding a right balance between supporting local economic development in new technology-intensive sectors and limiting the risks of backing unworthy target companies appears to be a major challenge in such regions. Turning to performance measures based on staging, syndication, successful exit through IPO/acquisition or negative exit 
through write-off, our results suggest that hybrid VC funds still tend to be more effective in hightech regions, whereas they experience more difficulties in low-tech ones.

As one of the main goals of these funds is to foster economic growth in less promising geographical areas, it is important to further improve the impact of these programmes along two main directions: first, stimulate equity investments in these areas to improve the environment for new and growing young enterprises and, second, increase the quality and the number of growth oriented companies to attract further investors. These two directions are complementary to each other as they allow to address the equity gap from both the supply and the demand side by increasing the number of investors for growth-oriented companies and the number of valuable opportunities for investors.

Perhaps, all too often regional social and economic disparities are addressed through public programmes that nominally have no geographic or social element and are designed to promote exclusively innovation or entrepreneurial behavior. Thus, more effort is needed to level off the disparity in the regional supply of private $\mathrm{VC}$ finance that is reflected also in the skewed distribution of entrepreneurial and innovation opportunities among regions. To make more precise, there is more VC finance in London and in the South East because there is more opportunity for attractive investment in these advanced regions. Thus, if the government is concerned to encourage enterpreneurship or innovation, hybrid VC funds need to have a greater impact also in low-tech regions to avoid the danger to support a process of cumulative causation and disparities in which some regions become centres of entrepreneurial finance while others have a much weaker engagement with risk capital.

Finally, we would like to pointed out that even if this study do not directly measure the performance of hybrid funds in terms of quantitative criteria such as investment returns or economic outcomes, it provides policy makers with useful insight to better understand along which directions existing and future public interventions should move to fully address the equity gap. The ideal framework is to create programmes able to address the equity gap both from the demand and supply side, taking into consideration the regional specificities, in order to improve the quality of investment opportunities and create an environment in which equity financing is more easily available. 


\section{REFERENCES}

Armour, J., Cumming, D.J., 2006. The legislative road to Silicon Valley, Oxford Economic Papers.

Avnimelech, A, Teubal, M., 2006. Creating venture capital industries that co-evolve with high tech: Insights from an extended industry life cycle perspective of the Israeli experience, Research Policy $35,1477-1498$.

Boyns, N., Cox, M., Spires, R. Hughes, A.. 2003. Research into the Enterprise Investment Scheme and Venture Capital Trusts: PACEC - Inland Revenue.

Brander, J.A., Amit, R., Antweiler, W., 2002. Venture capital syndication: improved venture selection versus the value-added hypothesis. Journal of Economics and Management Strategy 11, $423-452$.

Cowling, M., Bates, P., Jagger, N. Murray, G.. 2008. Study of the impact of the Enterprise Investment Scheme (EIS) and Venture Capital Trusts (VCTs) on company performance: HM Revenue \& Customs Research Report 44.

Cressy, R., 1996. Are business startups debt-rationed? Economic Journal 106, 1253-1270.

Cressy, R., 2002. Funding gaps: a symposium. Economic Journal, 112(477): F1-F16.

Cressy R., Olofsson, C. 1997. The financial conditions for Swedish SMEs: Survey and research agenda. Small Business Economics, 9(2): 179-192.

Cumming, D.J. 2007 Government policy towards entrepreneurial finance: Innovation investment funds Journal of Business Venturing 22, 193 - 235.

Cumming, D.J., Dai, N. 2009. Local bias in venture capital investments. Journal of Empirical Legal Studies, forthcoming.

Cumming, D.J., MacIntosh, J.G., 2003. A cross-country comparison of full and partial venture capital exits. Journal of Banking and Finance 27, 511 - 548.

Cumming, D.J., MacIntosh, J.G., 2006. Crowding out private equity: Canadian evidence. Journal of Business Venturing, 21, 569-609.

European Commission. 2005. Best practices of public support for early-stage equity finance. Brussels: European Commission.

Gilson, R. 2002. Engineering a venture capital market: lessons from the American experience. Stanford Law Review, 55: 1067.

Gompers, P.A., Lerner, J., 2001. The Money of Invention: How Venture Capital Creates New Wealth. Harvard. Business School Press, Cambridge.

Gompers, P.A., Kovner, A., Lerner, J. Scharfstein, D. 2008. Venture capital investment cycles: The impact of public markets. Journal of Financial Economics, 87(1), 1-23 
Hochberg Y., Ljungqvist A., Lu Y (2007). Whom You Know Matters: Venture Capital Networks and Investment Performance. Journal of Finance, 62(1).

Hyytinen A., Väänänen, L. 2006. Where do financial constraints originate from? An empirical analysis of adverse selection and moral hazard in capital markets. Small Business Economics, 27(4): 323-348.

Jääskeläinen, M., Maula, M.V.J., \& Murray G.C. 2007. Profit Distribution and Compensation Structures in Publicly and Privately Funded Hybrid Venture Capital Funds. Research Policy 36(7): 913-929.

Kanniainen, V., Keuschnigg, C. 2004. Start-up investment with scarce venture capital support. Journal of Banking and Finance, 28(8): 1935-1959.

Leleux, B., Surlemont, B., 2003. Public versus private venture capital: seeding or crowding out? A Pan-European analysis. Journal of Business Venturing 18, 81- 104.

Lerner, J., 1999. The government as venture capitalist: the long-run effects of the SBIR Program. Journal of Business 72, 285-318.

Lerner, J., 2002a. Boom and bust in the venture capital industry and the impact on innovation. Federal Reserve Bank of Atlanta Economic Review, 4, 25 - 39.

Lerner, J., 2002b. When bureaucrats meet entrepreneurs: the design of effective public venture capital programmes. Economic Journal 112, 73-84.

Lockett, A., Murray, G., Wright, M. (2002) Do UK venture capitalists still have a bias against investment in new technology firms, Research Policy, 31, 1009-1030

Macmillan. H. 1931. Report of the Committee on Finance and Industry. London: HMSO. Manchester Business School. 1999. The Financial Development of Smaller Private and Public SMEs.

Mason, C, Harrison, R. 2003. Closing the regional equity gap? A critique of the Department of Trade and Industry's Regional Venture Capital Funds initiative. Regional Studies, 37, 855-868.

Murray, G.C., 1998. A policy response to regional disparities in the supply of risk capital to new technology-based firms in the European union: the European seed capital fund scheme.

Regional Studies 32 (50), 405-419.

Murray, G.C., Lott, J., 1995. Have venture capitalists a bias against investment in new technology firms? Research Policy 24, 283-299.

Nightingale, P., Murray, G., Cowling, M., Baden-Fuller, C., Mason, C., Siepel, J. Hopkins, M., Dannreuther, C. 2009. From funding gaps to thin markets UK Government support for early-stage venture capital. BVCA and NESTA Research Report.

OECD. 2003. Venture Capital Policy Review: United Kingdom. Paris: Science Technology Industry, Organization for Economic Co-operation and Development. 
OECD. 2004. Venture Capital: Trends and Policy Recommendations. Paris: Science Technology Industry, Organization for Economic Co-operation and Development.

Powell, W.W., Koput, L., Smith-Doerr, L., Bowie, J. 2002. The Spatial Clustering of Science and Capital. Regional Studies 36(3):299-313.

Poterba. J. 1989. Capital gains tax policy toward entrepreneurship. National Tax Journal, 42(3): 375-389.

Sorenson, O. and T.E. Stuart, 2001. Syndication networks and the spatial distribution of venture capital investments. American Journal of Sociology, 1546-1588.

Sunley P., Klagge B., Berndt C. and Martin R., 2005. Venture capital programmes in the UK and Germany: in what sense regional policies?, Regional Studies 39(2), 255-273.

Wright M, Robbie K. 1998. Venture Capital and Private Equity: A Review and Synthesis. Journal of Business Finance \& Accounting, Vol. 25: 521 - 570. 


\section{TABLES AND FIGURES}

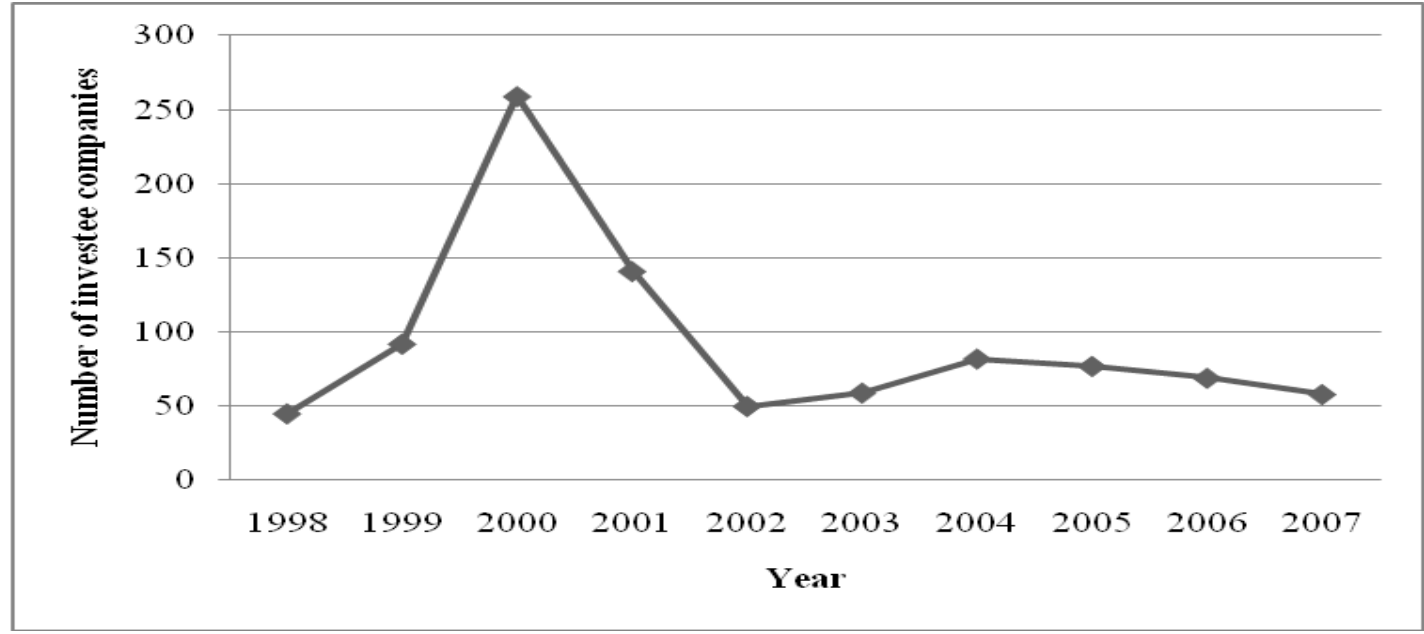

Fig. 1. This figure presents UK venture capital investments in the period 1998-2007.

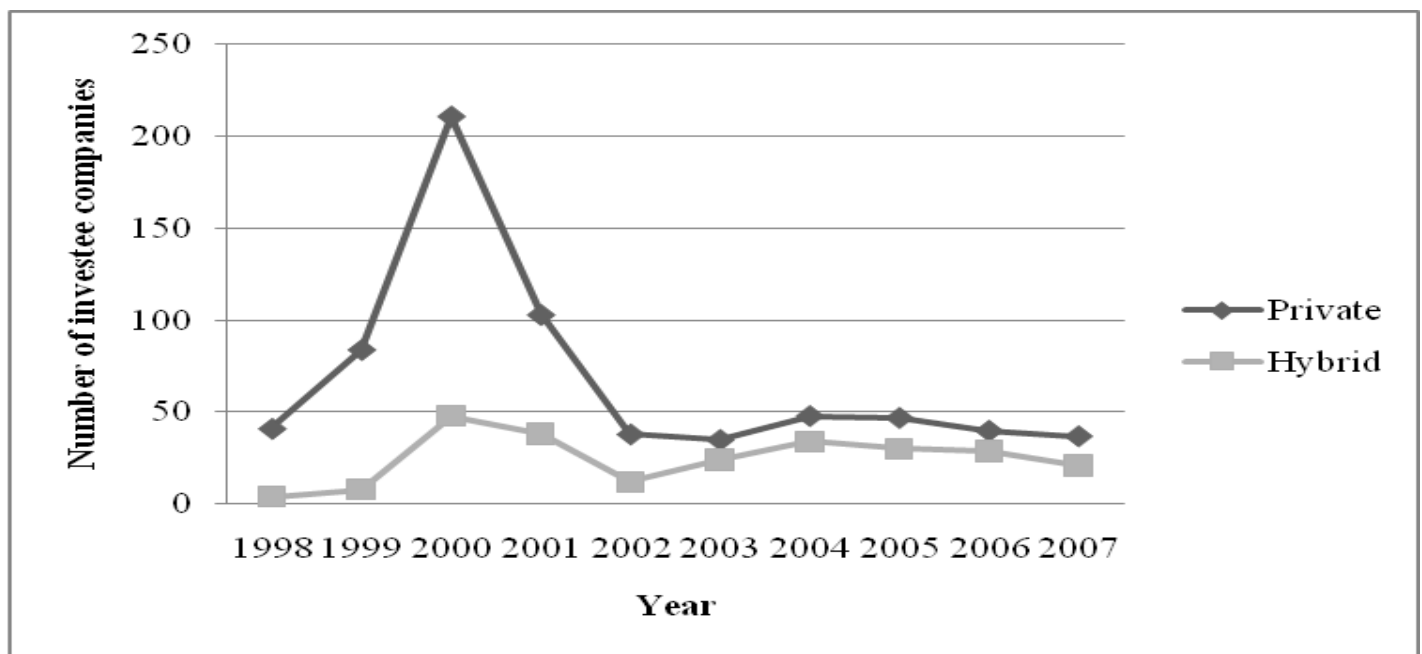

Fig. 2. This figure presents UK venture capital investments, by investor type, in the period 1998-2007.

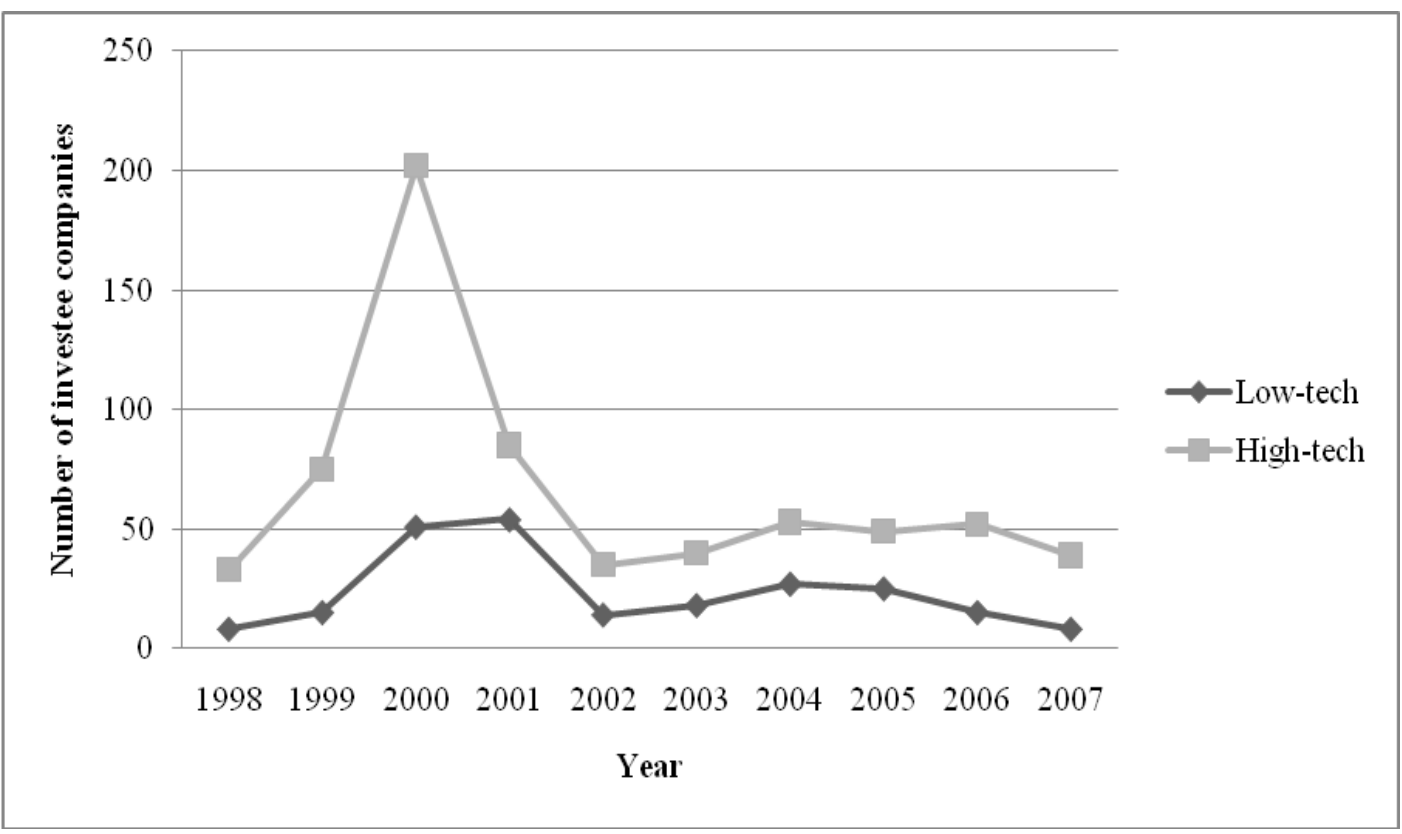

Fig. 3. This figure presents UK venture capital investments, by region, in the period 1998-2007. 
Table 1. Variable definitions.

\begin{tabular}{|c|c|c|}
\hline Variable Name & Definition & Source \\
\hline \multicolumn{3}{|c|}{ Dependent variables capturing the propensity to address the equity gap } \\
\hline Seed & $\begin{array}{l}\text { A dummy variable equal to one for companies funded in the seed/startup phase } \\
\text { according to the Venture Economics classification, and zero otherwise (for } \\
\text { companies funded in the early-stage phase) }\end{array}$ & $\begin{array}{l}\text { Venture } \\
\text { Economics }\end{array}$ \\
\hline $\begin{array}{l}\text { High-tech } \\
\text { Sector }\end{array}$ & $\begin{array}{l}\text { A dummy variable equal to one for companies operating in high-technology } \\
\text { sectors according to the Venture Economics classification (biotech, } \\
\text { medical/health, computer hw and sw, Internet related, semiconductors and } \\
\text { communications), and zero otherwise }\end{array}$ & $\begin{array}{l}\text { Venture } \\
\text { Economics }\end{array}$ \\
\hline \multicolumn{3}{|c|}{ Dependent variables capturing the ability to attract additional VC investments } \\
\hline Staging & The number of staged investment rounds in which VCs financed the company & $\begin{array}{l}\text { Venture } \\
\text { Economics }\end{array}$ \\
\hline Syndication & The number of syndicated VC investors for all of the financing rounds & $\begin{array}{l}\text { Venture } \\
\text { Economics }\end{array}$ \\
\hline $\begin{array}{l}\text { Foreign } \\
\text { Syndication }\end{array}$ & $\begin{array}{l}\text { The number of foreign (i.e not from the UK) syndicated VC investors for all of } \\
\text { the financing rounds }\end{array}$ & $\begin{array}{l}\text { Venture } \\
\text { Economics }\end{array}$ \\
\hline $\begin{array}{l}\text { Corporate } \\
\text { Syndication }\end{array}$ & $\begin{array}{l}\text { The number of corporate (i.e Corporate Venture Capital) syndicated VC investors } \\
\text { for all of the financing rounds }\end{array}$ & $\begin{array}{l}\text { Venture } \\
\text { Economics }\end{array}$ \\
\hline \multicolumn{3}{|c|}{ Dependent variables capturing the exit success of investee companies } \\
\hline IPO/Acquisition & $\begin{array}{l}\text { A dummy variable equal to one if the investee has been exited through an IPO or } \\
\text { an acquisition as of December 2007, according to the Venture Economics, and } \\
\text { zero otherwise }\end{array}$ & $\begin{array}{l}\text { Venture } \\
\text { Economics }\end{array}$ \\
\hline Failure & $\begin{array}{l}\text { A dummy variable equal to one for companies defunct or under bankruptcy } \\
\text { regime as of December 2007, according to the Venture Economics, and zero } \\
\text { otherwise }\end{array}$ & $\begin{array}{l}\text { Venture } \\
\text { Economics }\end{array}$ \\
\hline \multicolumn{3}{|c|}{ Explanatory variables } \\
\hline $\begin{array}{l}\text { Hybrid VC } \\
\text { Fund }\end{array}$ & $\begin{array}{l}\text { A dummy variable equal to one for companies financed by hybrid funds (backed } \\
\text { by both public and private sector money), and zero otherwise (companies backed } \\
\text { only by private VC funds) }\end{array}$ & $\begin{array}{l}\text { Venture } \\
\text { Economics and } \\
\text { other sources } \\
\text { (see Section 3.3) }\end{array}$ \\
\hline $\begin{array}{l}\text { High-tech } \\
\text { Region }\end{array}$ & $\begin{array}{l}\text { A dummy variable equal to one for companies located in an high-tech region (in } \\
\text { which the share of employment in high-tech or medium-high tech manufacturing } \\
\text { sectors is greater than } 10 \% \text { of total employment), and zero otherwise (companies } \\
\text { located in low-tech regions) }\end{array}$ & $\begin{array}{l}\text { Eurostat } \\
\text { (see Section 3.3) }\end{array}$ \\
\hline \multicolumn{3}{|l|}{ Control variables } \\
\hline MSCI & $\begin{array}{l}\text { The Morgan Stanley Capital International Index (MSCI) equity return (UK) } \\
\text { in the first round investment year. }\end{array}$ & Worldscope \\
\hline Bubble & A dummy variable equal to one for an exit in 1999 or 2000 (and zero otherwise) & $\begin{array}{l}\text { Venture } \\
\text { Economics }\end{array}$ \\
\hline Company Age & Number of years from the founding year to 2007 & $\begin{array}{l}\text { Venture } \\
\text { Economics }\end{array}$ \\
\hline $\begin{array}{l}\text { Investment } \\
\text { Duration }\end{array}$ & Number of years of investment (from the first round to the exit) & $\begin{array}{l}\text { Venture } \\
\text { Economics }\end{array}$ \\
\hline Age Funds & $\begin{array}{l}\text { The average age of all the funds in syndication that financed the investee } \\
\text { company }\end{array}$ & $\begin{array}{l}\text { Venture } \\
\text { Economics }\end{array}$ \\
\hline
\end{tabular}


Table 2. Summary statistics by investee companies.

\begin{tabular}{lccccc}
\hline Variable & Obs. & Mean & Std. Dev. & Min & Max \\
\hline Hybrid VC Fund & 898 & .2706013 & .444518 & 0 & 1 \\
High-tech Region & 898 & .7383073 & .4398011 & 0 & 1 \\
Seed & 898 & .4154535 & .4930762 & 0 & 1 \\
High-tech Sector & 898 & .5679287 & .4956402 & 0 & 1 \\
Staging & 898 & 1.513363 & 1.173062 & 1 & 11 \\
Syndication & 898 & 1.856347 & 1.624255 & 1 & 17 \\
Foreign Syndication & 898 & .5634744 & 1.063681 & 0 & 12 \\
Corporate Syndication & 898 & .1224944 & .3929785 & 0 & 3 \\
IPO/Acquisition & 898 & .1648107 & .3712164 & 0 & 1 \\
Failure & 898 & .0690423 & .2536674 & 0 & 1 \\
Company Age & 653 & 7.367534 & 4.169306 & 0 & 62 \\
Investment Duration & 898 & 5.151448 & 2.561921 & 0 & 9 \\
Average Fund Age & 898 & 9.100121 & 5.34401 & 0 & 39 \\
MSCI & 898 & .0040223 & .1239194 & -.257 & .16 \\
Bubble & 898 & .3819599 & .4861375 & 0 & 1
\end{tabular}

This table summarizes the data of the full sample by the average, standard deviation, minimum and maximum values. The number of observations for each variable is also indicated. 
Table 3. Correlation matrix

\begin{tabular}{|c|c|c|c|c|c|c|c|c|c|c|c|c|c|c|c|c|}
\hline & & (1) & (2) & (3) & (4) & (5) & (6) & (7) & (8) & (9) & (10) & (11) & $(12)$ & (13) & (14) & (15) \\
\hline (1) & Staging & 1 & & & & & & & & & & & & & & \\
\hline (2) & High-tech Region & 0.0187 & 1 & & & & & & & & & & & & & \\
\hline (3) & IPO/Acquisition & $\underline{0.1025}$ & 0.0391 & 1 & & & & & & & & & & & & \\
\hline (4) & Failure & -0.0368 & -0.0377 & $\underline{-0.1210}$ & 1 & & & & & & & & & & & \\
\hline (5) & Company Age & $\underline{0.0919}$ & -0.0178 & $\underline{0.1469}$ & 0.0378 & 1 & & & & & & & & & & \\
\hline (6) & Seed & 0.0269 & -0.0454 & -0.0495 & 0.0290 & $\underline{-0.1582}$ & 1 & & & & & & & & & \\
\hline (7) & High-tech Sector & $\underline{0.1787}$ & -0.0590 & 0.0239 & $\underline{-0.0728}$ & -0.0177 & 0.0540 & 1 & & & & & & & & \\
\hline (8) & Hybrid VC Fund & 0.0091 & $\underline{-0.0765}$ & $\underline{-0.1355}$ & -0.0176 & $\underline{-0.2006}$ & $\underline{0.1506}$ & $\underline{0.1366}$ & 1 & & & & & & & \\
\hline (9) & Syndication & $\underline{0.5033}$ & 0.0300 & $\underline{0.1392}$ & -0.0219 & -0.0013 & 0.0368 & $\underline{0.1818}$ & $\underline{0.1141}$ & 1 & & & & & & \\
\hline (10) & Foreign VCs & $\underline{0.2647}$ & $\underline{0.0892}$ & $\underline{0.1203}$ & -0.0039 & -0.0346 & -0.0051 & $\underline{0.0901}$ & -0.0588 & $\underline{0.6773}$ & 1 & & & & & \\
\hline (11) & Corporate VCs & $\underline{0.3157}$ & 0.0309 & 0.0525 & 0.0269 & -0.0222 & 0.0075 & $\underline{0.0946}$ & 0.0589 & $\underline{0.3594}$ & $\underline{0.2241}$ & 1 & & & & \\
\hline (12) & Average fund age & -0.0438 & -0.0033 & $\underline{0.1152}$ & 0.0220 & $\underline{0.1380}$ & 0.0565 & -0.0467 & $\underline{-0.1345}$ & $\underline{0.0725}$ & $\underline{0.1611}$ & -0.0084 & 1 & & & \\
\hline (13) & Investment duration & $\underline{0.0917}$ & 0.0491 & $\underline{0.2844}$ & $\underline{0.1760}$ & $\underline{0.4859}$ & 0.0597 & $\underline{-0.0757}$ & $\underline{-0.2465}$ & 0.0639 & $\underline{0.0709}$ & 0.0070 & $\underline{0.2813}$ & 1 & & \\
\hline (14) & MSCI & $\underline{-0.0904}$ & 0.0382 & -0.0285 & $\underline{-0.0677}$ & -0.0357 & -0.0654 & 0.0471 & $\underline{0.0662}$ & $\underline{-0.0716}$ & -0.0286 & -0.0333 & 0.0142 & $\underline{0.0732}$ & 1 & \\
\hline (15) & Bubble & -0.0373 & $\underline{0.1239}$ & $\underline{0.1759}$ & $\underline{0.2018}$ & $\underline{0.2676}$ & 0.0175 & $\underline{-0.1703}$ & $\underline{-0.1899}$ & -0.0081 & $\underline{0.0727}$ & -0.0409 & $\underline{0.1753}$ & 0.0258 & $\underline{-0.1177}$ & 1 \\
\hline
\end{tabular}

This table presents correlations across variables. Correlations statistically significant at the $5 \%$ level are highlighted in underline font. 
Table 4. Comparison of proportions and means for type (hybrid and private) of funds (A) in the full sample, (B) in high-tech regions and (C) low-tech regions.

\begin{tabular}{|c|c|c|c|c|c|c|c|c|c|c|c|c|c|c|c|}
\hline & \multicolumn{5}{|c|}{ (A) Full Sample } & \multicolumn{5}{|c|}{ (B) High-tech Region } & \multicolumn{5}{|c|}{ (C) Low-tech Region } \\
\hline & \multicolumn{2}{|c|}{ Hybrid (1) } & \multicolumn{2}{|c|}{ Private (0) } & $(0)-(1)$ & \multicolumn{2}{|c|}{ Hybrid (1) } & \multicolumn{2}{|c|}{ Private $(0)$} & $(0)-(1)$ & \multicolumn{2}{|c|}{ Hybrid (1) } & \multicolumn{2}{|c|}{ Private (0) } & $(0)-(1)$ \\
\hline & Obs. & $\begin{array}{c}\text { Proportion } \\
\text { or Mean }\end{array}$ & $O$ & $\begin{array}{c}\text { Proportion } \\
\text { or Mean }\end{array}$ & Difference & Obs. & $\begin{array}{c}\text { Proportion } \\
\text { or Mean }\end{array}$ & Obs. & $\begin{array}{c}\text { Proportion } \\
\text { or Mean }\end{array}$ & Difference & Obs. & $\begin{array}{c}\text { Proportion } \\
\text { or Mean }\end{array}$ & Obs. & $\begin{array}{c}\text { Proportion } \\
\text { or Mean }\end{array}$ & Difference \\
\hline Seed & 243 & .5371901 & 65 & .3701997 & $-.1669904 * * *$ & 166 & .4969697 & 497 & .3704453 & $-.1265244 * *$ & 77 & .6233766 & 158 & .3694268 & $-.2539499 * * *$ \\
\hline High-tech Sector & 243 & .6790123 & 65 & .5267176 & $-.1522948 * * *$ & 166 & .626506 & 497 & .5251509 & $-.1013551 * *$ & 77 & .7922078 & 158 & .5316456 & $-.2605622 * * *$ \\
\hline Staging & 243 & 1.530864 & 65 & 1.50687 & -.023994 & 166 & 1.590361 & 497 & 1.50503 & -.0853313 & 77 & 1.402597 & 158 & 1.512658 & .1100608 \\
\hline Syndication & 243 & 2.160494 & 65 & 1.743511 & $-.4169824 * * *$ & 166 & 2.295181 & 497 & 1.748491 & $-.5466898 * * *$ & 77 & 1.87013 & 158 & 1.727848 & -.1422818 \\
\hline Foreign Syndication & 243 & .4609053 & 65 & .6015267 & $.1406214 *$ & 166 & .5180723 & 497 & .6539235 & .1358513 & 77 & .3376623 & 158 & .4367089 & .0990465 \\
\hline Corporate Syndication & 243 & .1604938 & 65 & .1083969 & $-.0520969 *$ & 166 & .1626506 & 497 & .1187123 & -.0439383 & 77 & .1558442 & 158 & .0759494 & $-.0798948 *$ \\
\hline IPO/Acquisition & 243 & .0823045 & 65 & .1954198 & $.1131153 * * *$ & 166 & .0843373 & 497 & .2032193 & $.118882 * * *$ & 77 & .0779221 & 158 & .1708861 & $.092964 *$ \\
\hline Failure & 243 & .0617284 & 65 & .0717557 & .0100273 & 166 & .0662651 & 497 & .0623742 & -.0038908 & 77 & .0519481 & 158 & .1012658 & .0493178 \\
\hline
\end{tabular}

This table presents comparison of proportions tests (for seed, high-tech, health, ICT, IPO or acquisition and failure), and means tests (for staging, syndication, foreign VCs and corporate VCs) for both hybrid and private funds. The first three columns refer to the full sample, columns from 4 to 6 refer to the high-tech region and the last three refer to the low-tech region. *,**, *** Statistically significant at the $10 \%, 5 \%$ and $1 \%$ levels, respectively. 
Table 5. Logit regression analyses of (A) stage of development and (B) type of industry.

\begin{tabular}{|c|c|c|c|c|c|c|}
\hline & \multicolumn{3}{|c|}{ (A) Seed } & \multicolumn{3}{|c|}{ (B) High-tech sector } \\
\hline & Full & $\begin{array}{l}\text { High-tech } \\
\text { Region }\end{array}$ & $\begin{array}{c}\text { Low-tech } \\
\text { Region }\end{array}$ & Full & $\begin{array}{c}\text { High-tech } \\
\text { Region }\end{array}$ & $\begin{array}{l}\text { Low-tech } \\
\text { Region }\end{array}$ \\
\hline & (1) & (2) & (3) & (4) & (5) & (6) \\
\hline Constant & $\begin{array}{c}0.211 * * * \\
(0.0486)\end{array}$ & $\begin{array}{l}-.3556533 \\
(.317857)\end{array}$ & $\begin{array}{c}-1.656258^{* * *} \\
(.696869)\end{array}$ & $\begin{array}{c}.0482552 \\
(.3095363)\end{array}$ & $\begin{array}{c}.0787291 \\
(.3098948)\end{array}$ & $\begin{array}{l}-.2486458 \\
(.5603097)\end{array}$ \\
\hline \multicolumn{7}{|l|}{ Fund characteristics } \\
\hline Hybrid VC Fund & $\begin{array}{c}0.211^{* * * *} \\
(0.0486)\end{array}$ & $\begin{array}{c}0.184 * * * \\
(0.0565)\end{array}$ & $\begin{array}{c}0.308 * * * \\
(0.101)\end{array}$ & $\begin{array}{l}0.111 * * \\
(0.0454)\end{array}$ & $\begin{array}{c}0.0891 \\
(0.0544)\end{array}$ & $\begin{array}{l}0.180 * * \\
(0.0829)\end{array}$ \\
\hline High-tech Region & $\begin{array}{c}-0.0220 \\
(0.0474)\end{array}$ & & & $\begin{array}{r}-0.00765 \\
(0.0459)\end{array}$ & & \\
\hline \multicolumn{7}{|l|}{ Market conditions } \\
\hline MSCI & $\begin{array}{l}-0.150 \\
(0.170)\end{array}$ & $\begin{array}{l}-0.0644 \\
(0.195)\end{array}$ & $\begin{array}{l}-0.344 \\
(0.364)\end{array}$ & $\begin{array}{c}0.182 \\
(0.168)\end{array}$ & $\begin{array}{c}0.181 \\
(0.196)\end{array}$ & $\begin{array}{c}0.229 \\
(0.345)\end{array}$ \\
\hline Bubble & $\begin{array}{c}-0.0100 \\
(0.0518)\end{array}$ & $\begin{array}{r}-0.00979 \\
(0.0591)\end{array}$ & $\begin{array}{l}0.0287 \\
(0.113)\end{array}$ & $\begin{array}{c}-0.187 * * * \\
(0.0522)\end{array}$ & $\begin{array}{c}-0.241 * * * \\
(0.0592)\end{array}$ & $\begin{array}{l}0.0106 \\
(0.108)\end{array}$ \\
\hline \multicolumn{7}{|l|}{ Investee characteristics } \\
\hline Seed & & & & $\begin{array}{c}0.0270 \\
(0.0414)\end{array}$ & $\begin{array}{l}0.00814 \\
(0.0481)\end{array}$ & $\begin{array}{c}0.0843 \\
(0.0841)\end{array}$ \\
\hline Company Age & $\begin{array}{c}-0.0759 * * * \\
(0.0121)\end{array}$ & $\begin{array}{c}-0.0640 * * * \\
(0.0135)\end{array}$ & $\begin{array}{c}-0.118^{* * * *} \\
(0.0234)\end{array}$ & $\begin{array}{c}0.00184 \\
(0.00564)\end{array}$ & $\begin{array}{c}0.00830 \\
(0.00830)\end{array}$ & $\begin{array}{l}-0.00333 \\
(0.00799)\end{array}$ \\
\hline Investment Duration & $\begin{array}{c}0.0864 * * * \\
(0.0158)\end{array}$ & $\begin{array}{c}0.0684 * * * \\
(0.0175)\end{array}$ & $\begin{array}{c}0.152 * * * \\
(0.0342)\end{array}$ & $\begin{array}{c}0.0165 \\
(0.0125)\end{array}$ & $\begin{array}{c}0.0133 \\
(0.0152)\end{array}$ & $\begin{array}{c}0.0111 \\
(0.0253)\end{array}$ \\
\hline \multicolumn{7}{|l|}{ Fund characteristics } \\
\hline Average Fund Age & $\begin{array}{c}0.00621 \\
(0.00422)\end{array}$ & $\begin{array}{c}0.00341 \\
(0.00479)\end{array}$ & $\begin{array}{l}0.0208^{* *} \\
(0.00952)\end{array}$ & $\begin{array}{c}0.00218 \\
(0.00424)\end{array}$ & $\begin{array}{c}0.00161 \\
(0.00486)\end{array}$ & $\begin{array}{c}0.00459 \\
(0.00888)\end{array}$ \\
\hline Model diagnostics & & & & & & \\
\hline Model & Logit & Logit & Logit & Logit & Logit & Logit \\
\hline Loglikelihood & -399.0088 & -307.84071 & 85.181374 & -427.49797 & -319.55707 & -103.41832 \\
\hline Pseudo $\mathrm{R}^{2}$ & 0.0963 & 0.0704 & 0.2272 & 0.0271 & 0.0371 & 0.0362 \\
\hline Chi-squared & $85.05 * * *$ & $46.66 * * *$ & $50.08 * * *$ & $23.81 * *$ & $24.63 * * *$ & 7.78 \\
\hline N. obs. & 650 & 489 & 161 & 650 & 489 & 161 \\
\hline
\end{tabular}

This table presents logit regressions of the probability of investees in seed stage and in different industries. Explanatory variables include the type of venture capital fund (hybrid and private) and the type of region (with high or low percentage of employment in high-tech sectors). Control variables include market conditions (MSCI market conditions in the year of investment and a dummy variable equal to one for the bubble years of 1999 and 2000), investee characteristics (age company and investment duration) and fund characteristics (average age of the funds in syndication). The numbers indicated are the marginal effects, and not the traditional logit coefficients as the marginal effects allow to illustrate the probability of the dependent variable being observed as a direct result of the explanatory variable. Two specifications are presented for each dependent variable: models $1,4,7$ and 10 analyse the full sample while the others refer to the split sample between high-tech (models 2, 5, 8 and 11) and low-tech regions (models 3, 6, 9 and 12$) . * * *, * * *$ Significant at the 10,5 and $1 \%$ levels. 
Table 6. Poisson regression analyses of (A) staging, (B) syndication and (C-D) type of investor in syndication.

\begin{tabular}{|c|c|c|c|c|c|c|c|c|c|c|c|c|}
\hline & & (A) Stagir & & & (B) Syndicat & tion & (C) & Foreign Syn & dication & (D) & Corporate Syn & dication \\
\hline & Full & $\begin{array}{l}\text { High-tech } \\
\text { Region }\end{array}$ & $\begin{array}{l}\text { Low-tech } \\
\text { Region }\end{array}$ & Full & $\begin{array}{l}\text { High-tech } \\
\text { Region }\end{array}$ & $\begin{array}{c}\text { Low-tech } \\
\text { Region }\end{array}$ & Full & $\begin{array}{l}\text { High-tech } \\
\text { Region }\end{array}$ & $\begin{array}{c}\text { Low-tech } \\
\text { Region }\end{array}$ & Full & $\begin{array}{l}\text { High-tech } \\
\text { Region }\end{array}$ & $\begin{array}{l}\text { Low-tech } \\
\text { Region }\end{array}$ \\
\hline & (1) & (2) & (3) & (4) & (5) & (6) & (7) & (8) & (9) & (10) & (11) & (12) \\
\hline Constant & \begin{tabular}{|l}
$.293849 * *$ \\
$(.1221607)$
\end{tabular} & $\begin{array}{l}.2406652^{* * *} \\
(.1232945)\end{array}$ & $\begin{array}{l}.481708^{* * *} \\
(.2177822)\end{array}$ & $\begin{array}{l}.3229469 * * \\
(.1098309)\end{array}$ & $\begin{array}{c}.3602791 \text { **** } \\
(.1105079)\end{array}$ & $\begin{array}{l}.4296433^{* * *} \\
(.1972109)\end{array}$ & \begin{tabular}{|l}
$-.9649951 * * *$ \\
$(.1980126)$
\end{tabular} & $\begin{array}{c}-.5508045^{* * *} \\
(.1812464)\end{array}$ & $\begin{array}{c}-1.096123^{* *} \\
(.4140138)\end{array}$ & $\begin{array}{c}-2.207874 * * * \\
(.4247952)\end{array}$ & $\begin{array}{c}-2.054993 * * * \\
(.4002252)\end{array}$ & $\begin{array}{l}-.9539399 \\
(.8060111)\end{array}$ \\
\hline Fund characteristics & & & & & & & & & & & & \\
\hline Hybrid VC Fund & $\begin{array}{c}.1007166 \\
(.0734722) \\
.0348748 \\
(.0728127)\end{array}$ & $\begin{array}{l}.1472752 * \\
(.0860678)\end{array}$ & $\begin{array}{c}.0133641 \\
(.1434957)\end{array}$ & $\begin{array}{c}.3147719 * * * \\
(.0634201) \\
.0691513 \\
(.0650707)\end{array}$ & $\begin{array}{c}.3612923 * * * \\
(.0738497)\end{array}$ & $\begin{array}{l}.2112953 * \\
(.1252361)\end{array}$ & $\begin{array}{l}-.0413407 \\
(.1221073) \\
.3942723^{* *} \\
(.1272672)\end{array}$ & $\begin{array}{l}-.0511143 \\
(.1383662)\end{array}$ & $\begin{array}{l}.0558826 \\
(.2643729)\end{array}$ & $\begin{array}{c}.5553164 * * \\
(.2288674) \\
.3778537 \\
(.2663844)\end{array}$ & $\begin{array}{l}.5759325 * * \\
(.2601809)\end{array}$ & $\begin{array}{l}.4862875 \\
(.4921481)\end{array}$ \\
\hline Marke & & & & & & & & & & & & \\
\hline MSCI & $\begin{array}{l}-.4718964 * \\
(.2537538)\end{array}$ & $\begin{array}{c}-.5701659 * * \\
(.2885784)\end{array}$ & $\begin{array}{l}-.235015 \\
(.5514462)\end{array}$ & $\begin{array}{c}-.5349861 * * \\
(.2293062)\end{array}$ & $\begin{array}{c}-.6090593 * * \\
(.260331)\end{array}$ & $\begin{array}{l}-.4939561 \\
(.504089)\end{array}$ & $\begin{array}{l}-.3845738 \\
(.4120569)\end{array}$ & $\begin{array}{l}-.4690922 \\
(.4496232)\end{array}$ & $\begin{array}{l}-.0546562 \\
(1.088749)\end{array}$ & $\begin{array}{c}-.595087 \\
(.8513974)\end{array}$ & $\begin{array}{l}-.3449585 \\
(.9234856)\end{array}$ & $\begin{array}{c}-3.114226 \\
(2.49045)\end{array}$ \\
\hline Bubble & $\begin{array}{c}-.2171464 * * \\
(.0788915)\end{array}$ & $\begin{array}{c}-.2796679 * * \\
(.0892258)\end{array}$ & $\begin{array}{c}.011382 \\
(.1706926)\end{array}$ & $\begin{array}{c}-.1409519^{* *} \\
(.0711411)\end{array}$ & $\begin{array}{c}-.2403188 * * \\
(.0802232)\end{array}$ & $\begin{array}{l}.1847692 \\
(.1545028)\end{array}$ & $\begin{array}{c}.0208 \\
(.1256335)\end{array}$ & $\begin{array}{l}-.1262868 \\
(.1364173)\end{array}$ & $\begin{array}{l}.7904291 * * \\
(.3214773)\end{array}$ & $\begin{array}{c}-.5486667 * * \\
(.2799622)\end{array}$ & $\begin{array}{l}-.674767 * * \\
(.2970379)\end{array}$ & $\begin{array}{c}.477767 \\
(.8068216)\end{array}$ \\
\hline Investee & & & & & & & & & & & & \\
\hline Company Age & $\begin{array}{l}.0152937 * * \\
(.0072777)\end{array}$ & $\begin{array}{l}.0324748 * * \\
(.0104811)\end{array}$ & $\begin{array}{l}-.0042866 \\
(.0143392)\end{array}$ & $\begin{array}{l}-.0007203 \\
(.0085372)\end{array}$ & $\begin{array}{l}-.0017895 \\
(.011369)\end{array}$ & $\begin{array}{l}.0006609 \\
(.0126412)\end{array}$ & $\begin{array}{c}-.0567865 * * \\
(.0219379)\end{array}$ & $\begin{array}{c}-.0455145^{* *} \\
(.0227345)\end{array}$ & $\begin{array}{c}-.1525971 * * \\
(.0726479)\end{array}$ & $\begin{array}{l}-.0015408 \\
(.0325479)\end{array}$ & $\begin{array}{l}.0150569 \\
(.0375509)\end{array}$ & $\begin{array}{l}-.0367632 \\
(.1045295)\end{array}$ \\
\hline Investment Duration & $\begin{array}{l}.0464206^{* *} \\
(.0186265)\end{array}$ & $\begin{array}{l}.0404387 * \\
(.0219161)\end{array}$ & $\begin{array}{l}.0305641 \\
(.0419307)\end{array}$ & $\begin{array}{c}.0335788^{* *} \\
(.017291)\end{array}$ & $\begin{array}{l}.0467686^{* *} \\
(.0200652)\end{array}$ & $\begin{array}{l}-.0131566 \\
(.0372464)\end{array}$ & $\begin{array}{l}.0475035 \\
(.0337104)\end{array}$ & $\begin{array}{l}.0510608 \\
(.0354966)\end{array}$ & $\begin{array}{c}.054314 \\
(.1021646)\end{array}$ & $\begin{array}{l}.0549611 \\
(.0645607)\end{array}$ & $\begin{array}{l}.0879445 \\
(.0696138)\end{array}$ & $\begin{array}{l}-.2501749 \\
(.2011813)\end{array}$ \\
\hline Fund characteristic & & & & & & & & & & & & \\
\hline Average Fund Age & $\begin{array}{c}-.0184536^{* *} \\
(.0075616)\end{array}$ & $\begin{array}{c}-.0184342 * * \\
(.0088707)\end{array}$ & $\begin{array}{l}-.0198163 \\
(.0152105)\end{array}$ & $\begin{array}{l}.0121536^{* * *} \\
(.0057108)\end{array}$ & $\begin{array}{l}.0132276^{* *} \\
(.0065509)\end{array}$ & $\begin{array}{c}.011904 \\
(.0123178)\end{array}$ & $\begin{array}{c}.0421902^{* * * *} \\
(.0080916)\end{array}$ & $\begin{array}{c}.0406196 \text { *** } \\
(.0089725)\end{array}$ & $\begin{array}{l}.0673834 * * \\
(.0225918)\end{array}$ & $\begin{array}{l}-.0287997 \\
(.0274507)\end{array}$ & $\begin{array}{l}-.0284818 \\
(.0317494)\end{array}$ & $\begin{array}{c}-.0439239 \\
(.0625739)\end{array}$ \\
\hline Model diagnost & & & & & & & & & & & & \\
\hline $\begin{array}{l}\text { Model } \\
\text { Loglikelihood }\end{array}$ & $\begin{array}{c}\text { Poisson } \\
-954.16966\end{array}$ & $\begin{array}{c}\text { Poisson } \\
-716.35295\end{array}$ & $\begin{array}{c}\text { Poisson } \\
-233.30579\end{array}$ & $\begin{array}{c}\text { Poisson } \\
-1122.7658\end{array}$ & $\begin{array}{c}\text { Poisson } \\
-840.99825\end{array}$ & $\begin{array}{c}\text { Poisson } \\
-277.11337\end{array}$ & $\begin{array}{c}\text { Poisson } \\
-757.00065\end{array}$ & $\begin{array}{c}\text { Poisson } \\
-599.40919\end{array}$ & $\begin{array}{c}\text { Poisson } \\
-149.69012\end{array}$ & $\begin{array}{c}\text { Poisson } \\
-276.95971\end{array}$ & $\begin{array}{c}\text { Poisson } \\
-217.03514\end{array}$ & $\begin{array}{c}\text { Poisson } \\
-56.073398\end{array}$ \\
\hline Pseudo R ${ }^{2}$ & 0.0154 & 0.0237 & 0.0084 & 0.0173 & 0.0228 & 0.0168 & 0.0289 & 0.0214 & 0.0754 & 0.0268 & 0.0279 & 0.0750 \\
\hline Chi-squared & $29.77 * * *$ & $34.77 * * *$ & 3.97 & $39.61 * * *$ & $39.32 * * *$ & 9.48 & $45.08 * * *$ & $26.16^{* * * *}$ & $24.42 * * *$ & $15.26^{*}$ & $12.47 *$ & 9.09 \\
\hline N. obs. & 650 & 489 & 161 & 650 & 489 & 161 & 650 & 489 & 161 & 650 & 489 & 161 \\
\hline
\end{tabular}

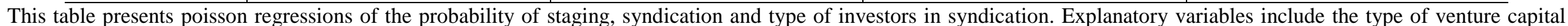

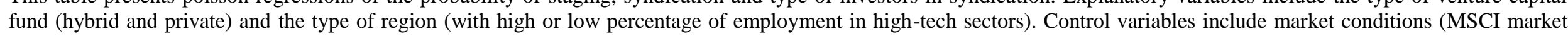

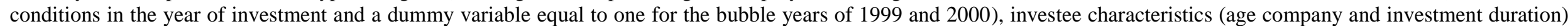




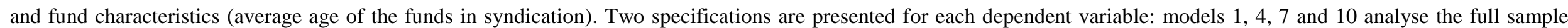

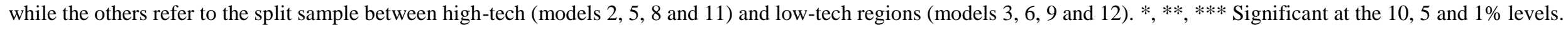


Table 7. Logit regression analyses of (A) positive exit and (B) failure.

\begin{tabular}{|c|c|c|c|c|c|c|}
\hline & \multicolumn{4}{|c|}{ (A) IPO/Acquisition } & \multicolumn{2}{|l|}{ (B) Failure } \\
\hline & Full & $\begin{array}{l}\text { High-tech } \\
\text { Region }\end{array}$ & $\begin{array}{l}\text { Low-tech } \\
\text { Region }\end{array}$ & Full & $\begin{array}{l}\text { High-tech } \\
\text { Region }\end{array}$ & $\begin{array}{l}\text { Low-tech } \\
\text { Region }\end{array}$ \\
\hline & (1) & (2) & (3) & (4) & (5) & (6) \\
\hline Constant & $\begin{array}{c}-3.973427 * * * \\
(.5563297)\end{array}$ & $\begin{array}{c}-4.505888 * * * \\
(.7127309)\end{array}$ & $\begin{array}{c}-3.189356^{* * * *} \\
(.8297059)\end{array}$ & $\begin{array}{c}-3.218948 * * * * \\
(.8958155)\end{array}$ & $\begin{array}{c}-4.746468 * * * * \\
(1.214952)\end{array}$ & $\begin{array}{l}-2.255338^{*} \\
(1.352413)\end{array}$ \\
\hline Fund characteristics & & & & & & \\
\hline $\begin{array}{l}\text { Hybrid VC Fund } \\
\text { High-tech Region }\end{array}$ & $\begin{array}{c}-0.0384 \\
(0.0327) \\
-0.00366 \\
(0.0314)\end{array}$ & $\begin{array}{l}-0.0346 \\
(0.0367)\end{array}$ & $\begin{array}{l}-0.0415 \\
(0.0655)\end{array}$ & $\begin{array}{c}0.00177 \\
(0.0171) \\
-0.0429 * * \\
(0.0211)\end{array}$ & $\begin{array}{c}0.0266 \\
(0.0211)\end{array}$ & $\begin{array}{c}-0.0760^{* *} \\
(0.0349)\end{array}$ \\
\hline Market conditions & & & & & & \\
\hline MSCI & $\begin{array}{c}-0.0753 \\
(0.111)\end{array}$ & $\begin{array}{l}-0.160 \\
(0.122)\end{array}$ & $\begin{array}{l}0.135 \\
(0.243)\end{array}$ & $\begin{array}{l}-0.0471 \\
(0.0595)\end{array}$ & $\begin{array}{l}0.01000 \\
(0.0590)\end{array}$ & $\begin{array}{l}-0.264^{*} \\
(0.152)\end{array}$ \\
\hline Bubble & $\begin{array}{l}-0.0276 \\
(0.0288)\end{array}$ & $\begin{array}{l}-0.0252 \\
(0.0309)\end{array}$ & $\begin{array}{l}-0.0357 \\
(0.0646)\end{array}$ & $\begin{array}{l}0.0454^{*} \\
(0.0232)\end{array}$ & $\begin{array}{l}0.0392 * \\
(0.0231)\end{array}$ & $\begin{array}{c}0.0754 \\
(0.0683)\end{array}$ \\
\hline Investee characteristic & & & & & & \\
\hline Seed & $\begin{array}{l}-0.0399 \\
(0.0269)\end{array}$ & $\begin{array}{l}-0.0415 \\
(0.0288)\end{array}$ & $\begin{array}{l}-0.0183 \\
(0.0617)\end{array}$ & $\begin{array}{l}-0.0235^{*} \\
(0.0134)\end{array}$ & $\begin{array}{l}-0.0215^{*} \\
(0.0128)\end{array}$ & $\begin{array}{l}-0.0119 \\
(0.0317)\end{array}$ \\
\hline Company Age & $\begin{array}{l}-0.000691 \\
(0.00442)\end{array}$ & $\begin{array}{l}-4.89 \mathrm{e}-05 \\
(0.00483)\end{array}$ & $\begin{array}{l}-0.00286 \\
(0.00950)\end{array}$ & $\begin{array}{l}-0.00397 \\
(0.00323)\end{array}$ & $\begin{array}{l}-0.00309 \\
(0.00309)\end{array}$ & $\begin{array}{l}-0.00215 \\
(0.00700)\end{array}$ \\
\hline Investment Duration & $\begin{array}{c}0.0559 * * * \\
(0.00878)\end{array}$ & $\begin{array}{c}0.0602 * * * \\
(0.00964)\end{array}$ & $\begin{array}{c}0.0463 * * \\
(0.0195)\end{array}$ & $\begin{array}{l}0.0131 * * \\
(0.00545)\end{array}$ & $\begin{array}{l}0.0124 * * \\
(0.00504)\end{array}$ & $\begin{array}{l}0.00194 \\
(0.0149)\end{array}$ \\
\hline Fund characteristics & & & & & & \\
\hline Average Fund Age & $\begin{array}{c}0.00186 \\
(0.00280)\end{array}$ & $\begin{array}{c}0.00161 \\
(0.00295)\end{array}$ & $\begin{array}{c}0.00157 \\
(0.00653)\end{array}$ & $\begin{array}{c}-0.00231 \\
(0.00184)\end{array}$ & $\begin{array}{l}-0.00227 \\
(0.00183)\end{array}$ & $\begin{array}{l}-0.00131 \\
(0.00412)\end{array}$ \\
\hline Model diagnostics & & & & & & \\
\hline Model & Logit & Logit & Logit & Logit & Logit & Logit \\
\hline Loglikelihood & -281.66284 & -209.72975 & -70.486112 & -136.35873 & -88.758696 & -42.773913 \\
\hline Pseudo $\mathrm{R}^{2}$ & 0.1148 & 0.1340 & 0.0716 & 0.1086 & 0.1263 & 0.1424 \\
\hline Chi-squared & $73.09 * * *$ & $64.90 * * *$ & 10.88 & $33.24 * * *$ & $25.66 * * *$ & $14.21^{* *}$ \\
\hline N. obs. & 650 & 489 & 161 & 650 & 489 & 161 \\
\hline
\end{tabular}

This table presents logit regressions of positive exit (IPO or acquisition) and failure (bankruptcy and divestiture). Explanatory variables include the type of venture capital fund (hybrid and private) and the type of region (with high or low percentage of employment in high-tech sectors). Control variables include market conditions (MSCI market conditions in the year of investment and a dummy variable equal to one for the bubble years of 1999 and 2000), investee characteristics (age company and investment duration) and fund characteristics (average age of the funds in syndication). The numbers indicated are the marginal effects, and not the traditional logit coefficients as the marginal effects allow to illustrate the probability of the dependent variable being observed as a direct result of the explanatory variable. Two specifications are presented for each dependent variable: models 1 and 4 analyse the full sample while the others refer to the split sample between high-tech (models 2 and 5) and low-tech regions (models 3 and 6). *,**,*** Significant at the 10,5 and $1 \%$ levels. 


\section{APPENDIX}

Table A1. Venture capital investments by UK region.

\begin{tabular}{|c|c|c|c|c|}
\hline Region & High-tech & Total & Private & Hybrid \\
\hline Outer London & 1 & 172 & 143 & 29 \\
\hline Berkshire, Buckinghamshire and Oxfordshire & 1 & 96 & 78 & 18 \\
\hline Inner London & 1 & 90 & 76 & 14 \\
\hline East Anglia & 1 & 78 & 48 & 30 \\
\hline Surrey, East and West & 0 & 51 & 42 & 9 \\
\hline Eastern Scotland & 0 & 46 & 33 & 13 \\
\hline Gloucestershire, Wilt & 1 & 46 & 34 & 12 \\
\hline South Western Scotland & 0 & 33 & 20 & 13 \\
\hline Hampshire and Isle of Wight & 1 & 27 & 18 & 9 \\
\hline Greater Manchester & 1 & 26 & 17 & 9 \\
\hline South Yorkshire & 0 & 21 & 10 & 11 \\
\hline Bedfordshire and Hertfordshire & 1 & 20 & 16 & 4 \\
\hline East Wales & 0 & 17 & 8 & 9 \\
\hline West Midlands & 1 & 17 & 3 & 14 \\
\hline Northern Ireland & 0 & 13 & 10 & 3 \\
\hline Essex & 0 & 12 & 10 & 2 \\
\hline North Yorkshire & 0 & 12 & 6 & 6 \\
\hline West Yorkshire & 0 & 12 & 5 & 7 \\
\hline Northumberland and Tyne and Wear & 1 & 11 & 5 & 6 \\
\hline West Wales and The Valleys & 1 & 11 & 6 & 5 \\
\hline Cheshire & 1 & 9 & 7 & 2 \\
\hline Derbyshire and Nottinghamshire & 1 & 9 & 7 & 2 \\
\hline Leicestershire, Rutland and Northamptonshire & 1 & 9 & 5 & 4 \\
\hline North Eastern Scotland & 0 & 9 & 6 & 3 \\
\hline Herefordshire, Worcestershire and & 1 & 8 & 7 & 1 \\
\hline Shropshire and Staffordshire & 1 & 8 & 8 & 0 \\
\hline Merseyside & 1 & 7 & 7 & 0 \\
\hline Tees Valley and Durham & 1 & 7 & 3 & 4 \\
\hline Kent & 0 & 5 & 5 & 0 \\
\hline Lincolnshire & 1 & 4 & 2 & 2 \\
\hline Dorset and Somerset & 1 & 3 & 2 & 1 \\
\hline East Riding and North & 1 & 3 & 3 & 0 \\
\hline Lancashire & 0 & 3 & 3 & 0 \\
\hline Cornwall and Isles of & 0 & 1 & 0 & 1 \\
\hline Devon & 1 & 1 & 1 & 0 \\
\hline Highlands and Islands & 0 & 1 & 1 & 0 \\
\hline Total & & 898 & 655 & 243 \\
\hline
\end{tabular}

This table shows the distribution of venture capital investments (total, private and hybrid) by the 36 UK regions. The type of region (with high or low percentage of employment in high-tech or medium-high tech manufacturing industries) is also indicated. 